\title{
HUBUNGAN FUSSY EATING DAN EARLY CHILDHOOD CARIES
}

\author{
Muthiara Praziandite ${ }^{1)}$, Nur Alam Fajar ${ }^{2)}$,Rico Sitorus ${ }^{3)}$ \\ ${ }^{1,2,3}$ Program Studi Ilmu Kesehatan Masyarakat, Fakultas Kesehatan Masyarakat Universitas Sriwijaya \\ E-mail: muthidite@gmail.com
}

\begin{abstract}
Problems: Fussy Eating is an usual problematic eating behavior among children, but it has negative impact to children's health, including oral health. Early Childhood Caries (ECC) is the most common dental hard tissue disease. Prevalence of ECC in Indonesia is 90\% (Riskesdas, 2018). The Aim Of The Research:the purpose of this study is to is to understand the association between Fussy Eating and ECC of children..Research Method: this study is observational with cross-sectional design. Sampling was conducted with purposive sampling and total sample is 165 children between 3-5 years old with their mother. Subscale Food Fussiness of Children Eating Behaviour Questionnaire (CEBQ) is used to measure Fussy Eating behaviour of children. ECC was measured by def-t index. Data analysis using chi-square test.The Results: Prevalence of children with Fussy Eating is 50,9\%. This study found that Fussy Eating was significantly associated with ECC(p-value 0,010; OR = 2,380; 95\% CI 1,273-4,450).. Conclusions: Fussy Eating contribute on development of EC.
\end{abstract}

Keywords:Fussy Eating, Eating Behaviour, Early Childhood Caries (ECC)

\begin{abstract}
ABSTRAK
Permasalahan:Fussy Eating merupakan gangguan makan yang umum terjadi pada anak tetapi memilki dampak buruk bagi kesehatan, termasuk kesehatan gigi dan mulut. Early Childhood Caries (ECC) adalah penyakit jaringan keras gigi yang paling banyak terjadi pada anak dengan prevalensi mencapai 90\% (Riskesdas, 2018).Tujuan Penelitian:peneltian ini bertujuan untuk mengetahui hubungan Fussy Eating dan Early Chidhhood Caries (ECC) pada anak. Metode Penelitian:penelitian ini merupakan penelitian observasional dengan desain cross sectional.Pengambilan sampel dilakukan purposive sampling dengan jumlah sampel sebanyak 165 orang berusia 3-5 tahun beserta ibunya. Children Eating Behaviour Qutionnaire (CEBQ) subskala Food Fussiness digunakan untuk mengukur Fussy Eating pada anak.ECC diukur dengan index def-t.Analisis data menggunakan uji chisquare.Hasil:Prevalensi anak dengan Fussy Eating adalah 50,9\%. Terdapat hubungan bermakna antara Fussy Eating dan kejadian ECC pada anak (p-value $=0,010$; OR $=2,380 ; 95 \%$ CI 1,2734,450). Kesimpulan:Fussy Eating berkontribuasi dalam kejadian ECC.
\end{abstract}

Kata Kunci:Fussy Eating, Perilaku Makan, Early Childhood Caries (ECC) 


\section{PENDAHULUAN}

Makan merupakan kegiatan sehari-hari yang dilakukan makhluk hidup untuk bertahan hidup.Tujuan makan pada anak bukan hanya untuk mengatasi rasa lapar, tetapi juga untuk memenuhi kebutuhan nutrisi yang dibutuhkan dalam tumbuh kembang anak.Gangguan makan merupakan hal yang sering terjadi pada anak dan merupakan masalah umum yang dihadapi oleh orang tua.Penelitian sebelumnya melaporkan bahwa gangguan makan terjadi pada 25\% anak. Gangguan makan yang terjadi pada anak bervariasi, diantaranya berupa pilih-pilih makan, makan tidak teratur, makan berlebuhan, dan makan dengan lambat(Anandakrishna et al., 2014)

Pada balita, kebiasaan makan didasari oleh preferensi makanan mereka. Anak-anak dalam kelompok usia balita hanya memakan makanan yang mereka sukai atau yang tersedia di lingkungan mereka dan menolak untuk makan makanan yang tidak mereka sukai (Scaglioni , 2011). Pada tingkat yang lebih lanjut, anak menujukkan penolakkan terhadap makanan tertentu terutama makanan baru yang mereka kenal (food neophobia) dan juga mengonsumsi makanan tertentu dengan jumlah yang tidak adekuat serta menolak makanan dengan tekstur tertentu. Hal ini merupakan gangguan makan pada anak yang disebut Fussy Eating (Tharner, 2014).

Fussy Eating merupakan fokus masalah para ahli saat ini karena Fussy Eating berhubungan dengan peningkatan risiko berat badan rendah, rendahnya konsumsi sayur-sayuran, tidak memenuhi rekomendasi pangan sesuai usia, konflik orang tua-anak, dan dapat menyebabkan anorexia nervosa saat dewasa (Anandakrishna et al., 2014). Penelitian sebelumnya melaporkan sebanyak 53\% ibu merasa anaknya menghindari makanan tertentu dan sebanyak 34\% ibu melaporkan anaknya pilih-pilih makan (Nembhwani et al., 2020). Fussy Eating pada anak dapat menyebabkan kesehatan anak secara umum terganggu, termasuk kesehatan gigi dan mulut.

Early Childhood Caries (ECC) merupakan penyakit gigi dan mulut yang paling sering terjadi.ECC adalah adanya 1 atau lebih lesi karies (tidak terkavitasi atau berlubang), hilang (karena karies), atau restorasi pada permukaan gigi sulung pada anak kurang dari 71 bulan.Early Childhood Caries dikenal dikenal juga dengan "nursing bottle mouth", "bottle mouth caries", "nursing caries", atau "Baby bottle Tooth Decay" (AAPD, 2003). Prevalensi karies pada gigi anak di dunia mencapai. 60-90\% (WHO, 2015) dan prevalensi karies gigi anak di Indonesia mencapai 90\% (Riskesdas, 2018). ECC dapat menyebabkan proses makan anak terganggu sehingga pemenuhan nutrisi tidak tercukupi, berkurangnya rasa nyaman, dan tidak percaya diri. Penelitian Anandakrishna (2014) menyimpulkan bahwa terdapat hubungan perilaku makan dengan terjadinya karies gigi anak.Penelitian Nembhwaniet al. (2020) melaporkan terdapat bahwa Food Fussiness merupakan salah satu factor risiko ECC berdasarkan perilaku makan pada anak. Penelitian mengenai hubungan antara Fussy Eating dan ECC saat ini masih terbatas, Oleh karena itu, penelitian tertarik untuk melakukan penelitian yang bertujuan untuk mengetahui hubungan Fussy Eating dan ECC. 


\section{METODE PENELITIAN}

Penelitian ini merupakan penelitian observasional dengan desain cross sectional yang dilakukan di Kota Palembang pada bulan November 2020.Jumlah sampel pada penelitian ini adalah sebanyak 165 anak berusia 3-5 tahun beserta ibunya dengan pengambilan sampel melalui purposive sampling.Anak dengan alergi makanan, penyakit sistemik, dan dalam pengobatan jangka panjang tidak diikutkan dalam penelitian. Pengambilan data Fussy Eating menggunakan Children Eating Behaviour Questionnaire (CEBQ) subskala Food Fussiness yang terdiri dari 6 pernyataan ibu/pengasuh yang menilai sikap pilih-pilih makan pada anak. Perntayaan tersebut, diantarnya: Anak saya menolak saat pertama kali mencoba makanan baru, Anak saya senang mencoba makanan baru, Anak saya menikmati berbagai jenis makanan, Anak saya sulit disenangkan dengan makanan, Anak saya tertarik mencicipi makanan baru yang belum pernah dicoba sebelumnya, dan Anak saya memutuskan ia tidak suka makanana tertentu, bahkan sebelum ia mencicipinya. Kuisioner diisi menggunakan 4 skala likert, yaitu tidak pernah, kadang-kadang, sering dan selalu (Wardle, 2001).

Indeks DEF-T digunakan untuk mengukur tingkat keparahan karies pada anak. Indeks DEF$T$ dengan kategori $\mathrm{D}$ (Decayed) untuk jumlah gigi sulung yang rusak karena karies dan masih dapat ditambal, E (Extracted) untuk jumlah gigi sulung yang telah atau harus dicabut karena karies, dan $\mathrm{F}$ (Filled) untuk jumlah gigi sulung yang telah ditumpat atau direstorasi secara permanen (Hiremaht, 2011).Penelitian ini telah dilakukan uji etik di Fakultas Kesehatan Masyarakat Universitas Sriwijaya dengan nomor sertifikat 366/UN9.1.10/KKE/2020.

Analisis data dilakukan dengan analisis univariat untu mendeskripsikan distribusi frekuensi Fussy Eating dankejadian ECC. Kemudian, analasis bivariat dilakukan untuk mengetahui hubungan antara Fussy Eating dan kejadian ECC pada anak. Analisis yang digunakan adalah uji statistik chisquare menggunakan program pengolahan data statistik SPSS versi 20. Data hasil penelitian disajikan dalam bentuk tabel.

\section{HASIL}

Jumlah responden dalam peneltian ini sebanyak 165 orang yang terdiri dari laki-laki berjumlah 80 orang $(48,5 \%)$ dan perempuasan berjumlah 85 orang $(51,5 \%)$. Responden yang berusia 5 tahun berjumlah 148 orang $(89,7 \%)$ dan responden yang berusia 3-4 tahun berjumlah 17 orang $(10,3 \%)$.

Tabel 1. Distribusi Karakteristik Demografi Responden

\begin{tabular}{lcc}
\hline \multicolumn{1}{c}{ Variabel } & Frekuensi (N) & Persentase (\%) \\
\hline Jenis Kelamin & & \\
$-\quad$ Laki-laki & 80 & 48,5 \\
$-\quad$ Perempuan & 85 & 51,5 \\
Usia & 148 & 89,7 \\
$-\quad 5$ tahun & 17 & 10,3 \\
\hline$\quad$ 3-4 tahun & & \\
\hline
\end{tabular}


Hasil pengukuran Fussy Eating dengan CEBQ subskala Food Fussines disajikan dalam tabel 2 dan 3. Berdasarkan CEBQ didapatkan hasil anak memiliki Food Fussiness pada anak dengan kategori tinggi berjumlah 84 orang $(50,9 \%)$ dan rendah berjumlah 81 orang $(49,1 \%)$. Hasil uji statistik dengan alpha 5\% menujukkan terdapat hubungan bermakna antara Food Fussiness dan kejadian ECC pada anak (p-value $=0,010)$ dengan odd ratio sebedar 2,38.

Tabel 2. Hubungan Fussy Eating dan kejadian ECC

\begin{tabular}{|c|c|c|c|c|c|c|c|c|}
\hline \multirow{3}{*}{ Variabel } & \multicolumn{4}{|c|}{ Early Childhood Caries } & \multirow{2}{*}{\multicolumn{2}{|c|}{ Jumlah }} & \multirow{3}{*}{$P$ Value } & \multirow{3}{*}{$\begin{array}{l}\text { OR } \\
95 \% \mathrm{CI} \\
\end{array}$} \\
\hline & \multicolumn{2}{|c|}{ Tinggi } & \multicolumn{2}{|c|}{ Rendah } & & & & \\
\hline & $\mathrm{n}$ & $\%$ & $\mathrm{n}$ & $\%$ & $\mathrm{~N}$ & $\%$ & & \\
\hline \multicolumn{9}{|c|}{ Food Fussiness } \\
\hline Tinggi & 49 & 58,3 & 35 & 41,7 & 84 & 100 & \multirow{2}{*}{$0,010^{*}$} & \multirow{2}{*}{$\begin{array}{l}2,380 \\
(1,273-4,450\end{array}$} \\
\hline - Rendah & 30 & 37,0 & 51 & 63,0 & 81 & 100 & & \\
\hline
\end{tabular}

Tabel 3. Distribusi pernyataan CEBQ subkala Food Fussiness

\begin{tabular}{llccccc}
\hline No & \multicolumn{1}{c}{ CEBQ } & \multicolumn{4}{c}{ Early Childhood Caries } \\
\cline { 3 - 7 } & & \multicolumn{2}{c}{ Ya } & \multicolumn{3}{c}{ Tidak } \\
\cline { 3 - 7 } 1 & Anak saya menolak saat pertama kali mencoba makanan & $\mathrm{n}$ & $\%$ & $\mathrm{n}$ & $\%$ \\
\cline { 3 - 7 } & baru & 43 & 26 & 122 & 74 \\
2 & Anak saya senang mencoba makanan baru & 73 & 44,2 & 92 & 55,8 \\
3 & Anak saya menikmati berbagai jenis makanan & 57 & 34,5 & 102 & 65,5 \\
4 & Anak saya sulit disenangkan dengan makanan & 42 & 25,4 & 123 & 75,5 \\
5 & $\begin{array}{l}\text { Anak saya tertarik mencicipi makanan baru yang belum } \\
\text { pernah dicoba sebelumnya } \\
6\end{array}$ & 92 & 55,7 & 73 & 44,3 \\
& $\begin{array}{l}\text { Anak saya memutuskan ia tidak suka makanana tertentu, } \\
\text { bahkan sebelum ia mencicipinya }\end{array}$ & 63 & 38,2 & 102 & 61,8 \\
\hline
\end{tabular}

\section{PEMBAHASAN}

Fussy Eating atau pilih-pilih makan merupakan masalah yang semakin diperhatikan saat ini karena hubungannya dengan resiko tinggi terhadap berat badan anak rendah, konusmsi sayuran yang rendah, diet anak tidak memenuhi anjuran sesuai usia, dan gangguan makan berkelanjutan (Tharner, 2014).

Fussy Eating didefinisikan sebagai penolakan anak terhadap makanan baru (food neophobia) maupun makanan yang telah ia kenal, atau mau mengonsumis makanan tersebut namun dengan kuantitas yang tidak adekuat, atau anak tidak mau mengonsumsi makanan dengan jenis, rasa, dan tekstur tertent (Sjarif , 2014).

Penelitian terdahulu menunjukkan 53\% ibu merasa anaknya menghindari jenis makanan tertentu dan 34\% ibu melaporkan anaknya pilih-pilih makanan (Equit et al., 2013). Pada pernyataan dalam CEBQ subskala Food Fussinessyang menggambarkan food nephobia, menunjukan sebanyaj $26 \%$ anak menolak saat pertama kali mencoba makanan baru, 55,8\% anak tidak senang mencoba makanan baru, 44,35\% anak tidak tertarik mencicipi makanan baru yang belum pernah dicoba 
sebelumnya. Pada pernyataan yang menggabarkan variasi makan anak menunjukkan $44,2 \%$ anak menikmati berbagai jenis makanan dan 38,3\% anak memutuskan tidak menyukai makanan tertentu bahkan sebelum mencicipinya. Sebanyak $25,4 \%$ anak sulit disenangkan dengan maknan, artinya anak kurang minat terhadap makanan.

Berdasarkan hasil penelitian ini diketahui bahwa kejadian ECC lebih banyak terjadi pada balita dengan Food Fussiness tinggi (58,3\%) dan terdapat hubungan bermakna antara Food Fussiness dan kejadian ECC pada balita (p-value=0,010). Balita dengan Food Fussiness tinggi akan berisiko 2,4 kali lebih besar risiko untuk mengalami ECC dibandingkan dengan balita dengan Food Fussiness rendah.

Hal ini sejalan dengan hasil penelitian yang dilaporkan Nembhwani et al. (2020) yang melaukan studi case control terhadap 440 balita untuk mengetahui hubungan antara proses gangguan makan dan ECC. Penelitian ini melaporkan bahwa ECC dan Food Fussiness memiliki hubungan signifikan (p-value $=0,001)$ (Nembhwaniet al., 2020).

Diet dan kesahatan gigi dan mulut merupakan hal yang saling berhubungan. Diet yang baik sangat penting untuk perkembangan dan pemeliharaan gigi yang sehat.Gigi yang sehat penting dalam memungkinkan konsumsi makanan yang bervariasi dan sehat sepanjang siklus hidup.Faktor risiko ECC yang berkaitan dengan perilaku makan, diantaranya frekuensi, jumlah, waktu, dan cara pemberian makanan (Punitha et al., 2015). Anak-anak balita cenderung memiliki preferensi yang mencakup makanan dengan konsentrasi tinggi karbohidrat, gula, lemak, dan garam, sedangkan asupan makanan seperti sayuran dan buah-buahan lebih rendah jika dibandingkan dengan jumlah yang disarankan (Ramos dan Stein, 2000)

Penolakan anak terhadap makanan tertentu khususnya makanan sehat dapat menyebabkan defisiensi nutrisi yang baik untuk kesehatan gigi dan mulut. Defisiensi vitamin D dan kalisium menyebabkan hipo mineralisasi pada enamel yang mengakibatkan gigi rentan terjadi karies (Feldenset al., 2019).

Hasil penelitian ini bertentangan dengan hasil penelitian Anandhakrisna et al. (2014) dan Banerjeeet al.(2020) Penelitian tersebut menunjukkan tidak terdapat hubungan antara Food Fussiness dan ECC.Berbagai penelitian telah dilakukan sebelumnya, namun hubungan yang konsisten antara karies gigi dan defisiensi nutrisi belum ditemukan.Peran makro nutrient dalam terjadinya karies masih diperdebatkan, namun peran mikro nutrient, yaitu fluoride, telah terbukti berpengaruh dalam terjadinya karies.Berbagai penelitian pada umumnya menyimpulkan bahwa faktor nutrisi dapat mempengaruhi resistensi predisposisi gigi terhadap karies (Feldenset al., 2019).

Prefensi makan pada anak bergantung pada makanan yang anak suka dan tidak suka. Anak-anak umumnya lebih menyukai makanan dan minuman dengan rasa manis. Rasa manis memberikan rangsangan psikobiologis yang memicu peningkatan sensasi senang atau puas. 
Hal ini memicu peningkatan keinginan anakdalam mengunmsi makanan manis. (Scaglioni et al., 2011)

Anak-anak yang mengkonsumsi makanan manis misalnya permen dan coklat $>4$ kali sehari hampir 20 kali lebih mungkin untuk terjadi perkembangan karies. Peluang timbulnya karies adalah 7,00 (OR $=7,00)$ kali lebih tinggi pada anak yang memiliki kebiasaan sering minum minuman berkarbonasi ( $>4$ kali seminggu) dibandingkan dengan mereka yang tidak minum minuman berkarbonasi. Almushayt dkk. melaporkan bahwa peningkatan frekuensi makan sayur akan menurunkan risiko karies $(\mathrm{OR}=0,7)$ dibandingkan dengan anak yang jarang makan sayur (Kirthiga et al., 2019).

Tingkat paparan gula juga memperngaruhi perkembangan karies pada gigi anak.Marshall dalam studinya tentang peran makanan, cemilan, dan total paparan makanan dan minuman harian pada pengalaman karies pada anak-anak menemukan bahwa paparan gula yang lebih tinggi saat makanan ringan meningkatkan risiko karies (Moynihan et al., 2014). Penolakkan anak terhadap makanan baru merupkan hal yang sering terjadi.Orang tua sering kali berkecil hati saat anak menolak jenis makanan baru saat pertama disajikan, mengira anak-anak mereka tidak suka makanan tersebut, dan menyerah.Namun, paparan berulang dapat berkontribusi pada pengurangan food neophobia. Penerimaan makanan biasanya baru terjadi setelah 12-15 kali penyajian makanan (Ramos et al., 2000)

Dalam menghadapi anak Fussy Eating, orang tua harus memberikan contoh makan makanan sehat, menyajikan makanan dalam porsi kecil, menyajikan makanan dengan menarik, dan orang tua harus bersabar dan tenang dalam membujuk anak agar mau mencicipi makanan baru(Sjari et al., 2014).

\section{KESIMPULAN}

Fussy Eating pada anak merupakan gangguan makan yang umum terjadi.Fussy eating memiliki hubungan bermakna dengan kejadian ECC pada anak (p-value=0,010). Anak dengan Food Fussiness tinggi akan berisiko 2,4 kali lebih besar risiko untuk mengalami ECC dibandingkan dengan anak dengan Food Fussiness rendah. Penelitian ini diharapkan dapat memberikan informasi dan pemahanan pada orang tua mengenai mecncegah Fussy Eatingpada anak, menangani anak dengan Fussy Eating, dan meningkatkan kesadaran mengani dampak Fussy Eating terutama terhadap kesehatan gigi dan mulut.

\section{UCAPAN TERIMA KASIH}

Peneliti mengucapkan terima kasih kepada seluruh pihak yang telah berkontribusi dan berpartisipasi dalam penelitian ini. 


\section{DAFTAR PUSTAKA}

American Academy of Pediatric Dentistry.2003.Policy on Early Childhood Caries (ECC). In: Classifications, Consequencies and Preventive Strategies.Pediatric Dentistry, 25(7), 24-8.

Anandakrishna, L., Bhargav, N., Hegde, A.,2014. Problematic eating and its association with early childhood caries among 46-71-month-old children using Children's Eating Behavior Questionnaire (CEBQ): A cross sectional study. Indian Journal of Dental Research, 25(5), 602.

Banerjee, I., Kumar, G., Zahir, S., 2020. Original Resesearch Paper Prevalence of Eating Behavior in Children and its Association with Early Childhood Caries Among 36-71 Month-Olds Children: A Cross Sectional Study. International Journal of Scientific Research, 9(5),1-2.

Equit, M., Pälmke, M., Becker, N., at al. 2013.Eating problems in young children-a population-based study. Acta Paediatrica, 102(2), 149-155.

Feldens, C. A., Kramer, P. F., \& Vargas-Ferreira, F. 2019.The role of diet and oral hygiene in dental caries.In Pediatric restorative dentistry (pp. 31-55).Springer, Cham.

Hiremath, S. 2011. Textbook of preventive and community dentistry: Elsevier India.

Kirthiga, M., Murugan, M., Saikia, A., \& Kirubakaran, R. 2019.Risk Factors for Early Childhood Caries: A Systematic Review and Meta-Analysis of Case Control and Cohort Studies. Pediatric dentistry, 41(2), 95-112.

Moynihan, P., \& Petersen, P. E. 2004.Diet, nutrition and the prevention of dental diseases. Public health nutrition, 7(1a), 201-226.

Nembhwani, H. \& Winnier, J. 2020.Impact of problematic eating behaviour and parental feeding styles on early childhood caries. International journal of paediatric dentistry, 30(5), 619-625.

Punitha, V., Amudhan, A., Sivaprakasam, P., \& Rathanaprabu, V. 2015.Role of dietary habits and diet in caries occurrence and severity among urban adolescent school children. Journal of pharmacy \& bioallied sciences, 7(1),296.

Ramos, M., \& Stein, L. M. 2000.Development children's eating behavior. JournalPediatric, 76( 3), 229-37.

Riskesdas.(2018). Potret Sehat Indonesia dari Riskesdas 2018.Kemenkes RI Artikel.Retrived from http://www.depkes. go. id/article/view/18110200003/potret-sehat-indonesia-dari-riskesdas2018. html.

Ikatan Dokter Anak Indonesia.2014. Pendekatan Diagnosis dan Tata Laksana Masalah Makan pada Batita di Indonesia. Jakarta: UKK Nutrisi dan penyakit metabolik.

Scaglioni, S., Arrizza, C., Vecchi, F., 2011. Determinants of children's eating behavior. 94(6), 200611.

Tharner, A., Jansen, P. W., Kiefte-de Jong, J., 2014. Toward an operative diagnosis of fussy/picky eating: a latent profile approach in a population-based cohort. International Journal of Behavioral Nutrition and Physical Activity, 11(1), 1-11.

Wardle, J., Guthrie, C. A., Sanderson, S., \& Rapoport, L. 2001. Development of the children's eating behaviour questionnaire. The Journal of Child Psychology and Psychiatry and Allied Disciplines, 42(7), 963-970.

WHO. 2015. Oral health surveys: basic methods.World Health Organization. 